\title{
The impact of new information services on teaching, learning and research at the University of Zululand Library
}

\author{
Lyudmila Ocholla ${ }^{1}$, Grace Mutsvunguma ${ }^{2}$ and Zanele Hadebe ${ }^{3}$ \\ Ochollal@unizulu.ac.za ORCID: orcid.org/0000-0003-3753-8659 \\ MutsvungumaG@unizulu.ac.za ORCID: orcid.org/0000-0002-8007-6632 \\ HadebeZ@unizulu.ac.za ORCID: orcid.org/0000-0002-7782-6236
}

\begin{abstract}
Received: 06 November 2016
Accepted: 20 January 2017
\end{abstract}

\begin{abstract}
The rapidly-changing academic environment demands innovative library products, facilities and services. Libraries have to navigate shrinking budgets, currency fluctuations, and the high cost of print and e-resources. Other challenges include the growing need for research support services, improved information literacy, information client support services, and marketing of library services using social media. At the University of Zululand (UNIZULU) Library, information librarians have played a pivotal role in the training of the academic community on modern information services for teaching, learning and research support. The purpose of this paper is to report on the perceived impact of the new information services initiated by information librarians and to establish how these services have made a difference in the teaching, learning and research activities at the university. A case study of UNIZULU Library was conducted using survey data collected from a sample population of academic staff and a random selection of evaluation forms that were completed by the students. The results of the survey showed a positive response from UNIZULU Library users to the newly-developed information services system. The paper concludes by noting the challenges to the services and suggesting areas for improvement.
\end{abstract}

Keywords: Library instruction, information literacy, research support, academic libraries, University of Zululand

\section{Introduction}

With seismic changes in the educational landscape stemming from the \#FeesMustFall protests ${ }^{4}$, the integration of Information and Communication Technology (ICT), and massive budget cuts, among other issues, libraries in South Africa are re-orienting themselves in order to remain relevant. Given that they have to compete with other departments for funding, libraries are increasingly being called upon to demonstrate their value in terms of contributing towards the mission and goals of their institutions. Now more than ever, the library has to fight for its place in the university by constantly reinventing itself and introducing new information services to cater for its users.

One of the University of Zululand's strategic goals states that the library is "expected to provide quality services to support teaching and learning and research" (University of Zululand 2016). In light of this, librarians at the institution continue to play a vital role in the development of modern information services for undergraduates, postgraduates, academics and researchers. They serve a student population of 17,687 students: 1,883 postgraduate students (Honours, Master's and Doctorate) and 15,804 undergraduates ${ }^{5}$. The prevalence of information technology has seen the academic community, ranging from lecturers and researchers to students, preferring to search for information themselves. Information professionals are now required to provide adequate support and training that borders on information literacy, which has recently been defined as "the set of integrated abilities encompassing the reflective discovery of information, the understanding of how information is produced and valued, and the use of information in creating new knowledge and participating ethically in communities of learning" (ACRL 2015).

In line with information literacy demands, UNIZULU Library set in motion structured training workshops on new library products and relevant research topics, such as access to e-resources, how to avoid plagiarism, reference management tools, citation resources, publishing, social media and informetrics among others. By introducing these services, UNIZULU Library has migrated from what Raju and Schoombee (2013:28) refer to as a "pull philosophy" to the "push philosophy" by taking its services to its users. This shift signifies and explains the changing role of librarians in service delivery and shows how they could be actively engaged with their clients, rather than taking a passive role by remaining 'locked away' in the libraries.

1. Lyudmila Ocholla is a Senior Librarian, Library and Information Services, University of Zululand, South Africa

2. Grace Mutsvunguma is an Information Librarian, Library and Information Services, University of Zululand, South Africa

3. Zanele Hadebe is an Information Librarian, Library and Information Services, University of Zululand, South Africa

4. The \#FeesMustFall protests, where students demanded, amongst other things, free university education, engulfed South African universities in 2015 and 2016

5. See http://registration.unizulu.ac.za:8080/groovy/enrol/enrolByLevel.groovy 
Information librarians are compelled to familiarise their users with these new services to ensure the effective and efficient use of the library and its resources. As a result, assessing the impact of the interventions and users' information literacy with respect to these new services becomes crucial. The aim of this paper was to determine whether these workshops/services have had any impact on students' performance.

\section{Literature review}

One of the recurring themes of the changing role of the academic librarian has been the teaching of information literacy, which is increasingly being regarded as crucial to students' learning and critical thinking (Bryan 2016). Today, librarians are actively involved in organising and conducting information literacy training workshops with library users. The importance of information literacy is highlighted by Shao and Purpur (2016) who argue that students' success, both academically and professionally, is predicated on how information literate they are. Shao and Purpur (2016) maintain that librarians, as experts in information management, should be at the forefront of this teaching and learning process.

Taking on these new responsibilities has required librarians to acquire new skills which they have done through workshops, informal engagements, personal development initiatives, seminars, conferences, research and self-training (Raju \& Schoombee 2013, Pasipamire 2015: 71). Westbrock and Fabian (2010: 585) opine that on-the-job training and selfeducation have provided librarians with the necessary skills to take on a teaching role. These skills also include communication or people skills, creativity, collaboration, and marketing skills (Schwartz 2016). UNIZULU mainly achieves its skills development through in-house training and knowledge sharing in a teamwork environment.

For most universities, research has become a strategic priority, and there is pressure on these institutions to produce more research in order to improve their rankings. Raju and Schoombee (2013:29) maintain that the librarian's role in the research process is so crucial that it has moved from being a supporter of the research process, to being a contributor. For quality research support services, librarians need to understand the research lifecycle (the stages of preparation, gathering, creation, preservation, sharing and measuring), discussed by Auckland (2012) and Schoombee (2013), to enable librarians to "intercept and support the researchers' work by identifying new services to support this cycle". Auckland (2012:16) explains that it is at the gathering stage that information librarians can offer researchers more targeted services, such as helping them to find information in their respective areas. Furthermore, the author acknowledges that recently librarians have become more involved at the measurement stage, where they provide training and advice on h-indices, bibliometrics, scholarly publishing and more. Tise, Raju and Adams (2015:10) conclude that "the status of the research support librarian is changing from reactive reference provider to proactive research partner".

While there are no specific models for new roles and services for academic libraries, the Association of College and Research Libraries (ACRL) (2011) has provided guidelines and standards for the development of models. Ocholla (2016:2) recommends that each academic library should choose a strategy for providing current facilities, products and services to fit their individual university's needs, budgets and priorities. In the case of UNIZULU Library, modern information services are developed and offered in the form of workshops on topics such as referencing management tools (Endnote or Mendeley); Turnitin; advanced search techniques for e-resources; social networks for researchers; and publishing and visibility.

Evaluating library performance and its impact is a practice that librarians have been engaged in for a long time (Han, Wong \& Webb 2011), so much so that professional bodies like the ACRL and the Association of Research Libraries (ARL) have developed various assessment tools ranging from surveys of users' opinions to statistical analyses. While Shao and Purpur (2016) support the view that librarians should empirically assess the impact of their training on students, some authors feel that many assessments done by libraries are half-hearted and lack empirical evidence (Matthew 2015). At UNIZULU Library, evaluation forms are distributed at the end of each training workshop in order to elicit responses from attendees. Like all evaluation/assessment exercises, this data helps to inform decisions on what changes should be implemented.

There is much literature on the positive impact of library instruction on students and researchers alike. Among the most recent studies, one by Liu, Lo and Itsumura (2016) assessed students' perception of library workshops; the response from students was positive. The students identified instruction on e-books or e-resources as particularly helpful to them.

Other studies include a survey at Oregon and Purdue Universities by Shao and Purpur (2016) which determined that students who attended library instruction workshops enhanced their critical thinking skills. Studies by Vance, Kirk and Gardner (2012) and Kot and Jones (2014) found that students who attended library instruction workshops utilised most of the library resources and therefore had higher Grade Point Averages (GPAs) than those who did not. Similarly, Wong and Cmor's (2011) analysis of library workshop attendance and the graduation GPAs of 8,000 students, found that library instruction seemed to have a positive impact on GPAs, suggesting that attending multiple library workshops impacts positively on academic success.

Bowles-Terry (2012) examined the connection between students' academic success and information literacy instruction. The students in the study disclosed that some of the skills gained during their library training assisted them with their research projects. Madukoma et al. (2013) conducted a similar study on library instruction and the academic performance of undergraduate students at Babcock University, Nigeria, where the majority of respondents stated that library instruction had a positive effect on their academic performance.

In order for library instruction to be fully appreciated, the importance of collaboration with other stakeholders in the institution must be taken into account (Kleinveldt, Schutte \& Stilwell 2016). In some instances, collaborations have led to the addition of information literacy to the curriculum, for example at the Cape Peninsula University of Technology and the Department of Engineering at the Durban University of Technology (Kleinveldt, Schutte \& Stilwell 2016: 64). Pham and 
Tanner (2014) also maintain that library-faculty collaborations not only give the library a chance to show off its expertise, but help to develop and enrich students' information and lifelong learning skills. A study by Shao and Purpur (2016) revealed that librarian and faculty collaborations in information literacy instruction improved students' written communication and academic performance.

\section{UNIZULU context}

UNIZULU Library, like other academic libraries, has been trying to find new ways to survive in the present competitive and technologically-advanced information environment. The results of a pilot study carried out by information librarians in 2015 on UNIZULU researchers to assess users' needs, underscored the need for change in the library by bringing to light the need to develop and maintain relevant and high-quality services, resources and facilities.

UNIZULU Library initiated change by re-designing existing and creating new library spaces, specifically the Research Commons (for researchers, Master's and PhD students) and Info Cellar (a space with networked computers for all students, particularly undergraduates). After evaluating its roles and position in the university structure, UNIZULU Library created library workshops as a new means of providing information services with only the few information librarians at its disposal. These workshops are focused on research support (for postgraduate students and researchers) and teaching and learning support (for undergraduate students and academics).

In describing the workshops, Ocholla (2016:5) explains that "information librarians selected the topics which were suitable for UNIZULU researchers", such as plagiarism, referencing management tools (for example, Endnote and Mendeley), social networks for researchers, publishing, visibility and research metrics. Topics were chosen to provide support at different stages of the research lifecycle. Suitable topics were explored and developed for undergraduate students and lecturers (such as plagiarism, e-resources and referencing, among others) to support teaching and learning.

In order to provide such services, Ocholla (2016:7) states that "information librarians performed their own knowledge audit to map those with advanced skills/knowledge, ranging from social media to bibliometrics, open access or referencing tools for knowledge sharing". The newly-introduced services were widely marketed and publicised through social media, library displays, posters, library presentations at faculty board meetings, research workshops and staff inductions.

New partnerships were established between the library and the Research and Innovation Office, the Teaching and Learning Centre, and faculty deans, to mention a few. These partnerships (which sometimes blossomed into collaborations) were highly effective in reaching the academic community at both undergraduate and postgraduate level.

Ocholla (2016:5) adds that UNIZULU's information librarians opened a file on Google Plus to manage their workshops. This file, "mirrors the activities related to the requested training workshops", and is used for statistical, planning and report writing purposes. Table 1 below provides a summary of the workshops conducted in 2015, highlighting the number of students (undergraduates - UG, postgraduates - PG) and academics (Acad) who attended the various workshops, and their respective faculties (Faculty of Arts - Arts; Science \& Agriculture - Sci; Commerce, Administration \& Law - CAL and Education - Edu).

Table 1 Library workshops, 2015

\begin{tabular}{|c|c|c|c|c|c|c|c|c|c|}
\hline Library Workshops & No. & Attend & Arts & Sci & Edu & CAL & UG & PG & Acad \\
\hline e-Resources, tips for searching and more! & 32 & 604 & 395 & 142 & 14 & 50 & 444 & 137 & 23 \\
\hline Everything you need to know about eBooks & 2 & 35 & 35 & & & & 35 & & \\
\hline Finding Theses and Dissertations : ETD & 5 & 49 & 49 & & & & 35 & 14 & \\
\hline ILL : Saving Time with Pre-Request & 3 & 5 & 4 & & & & 1 & 1 & 1 \\
\hline Know your library & 10 & 160 & 121 & 16 & & 23 & 50 & 110 & \\
\hline Publishing your research & 1 & 4 & 4 & & & & & 4 & \\
\hline Publishing, Impact factor \&visibility & 1 & 2 & 1 & & & & & & 1 \\
\hline Referencing made easy with Endnote & 12 & 122 & 107 & & 15 & & 16 & 69 & 36 \\
\hline Referencing made easy with Mendeley & 12 & 322 & 169 & 118 & 15 & 8 & 160 & 26 & 29 \\
\hline Researchers Social Networking & 2 & 9 & 8 & & & & 1 & & 1 \\
\hline Stay away from Plagiarism & 29 & 836 & 659 & 124 & 14 & 27 & 728 & 95 & 13 \\
\hline The use of Multimedia/AV materials & 2 & 30 & 30 & & & & 30 & & \\
\hline Turnitin : Plagiarism Checker & 7 & 110 & 67 & 14 & 13 & 7 & 51 & 18 & 11 \\
\hline Total & 118 & 2288 & 1649 & 414 & 71 & 115 & 1552 & 474 & 115 \\
\hline
\end{tabular}

\section{Methodology}

This case study sought to examine the impact of the new information services offered by the library to support teaching, learning and research activities at UNIZULU. The instruments for data collection consisted of questionnaires and evaluation forms. The population of this study included academics and students. 
A short questionnaire was designed to gather both quantitative and qualitative data from the academics. The questionnaire contained questions on demographics; reasons for visiting the library; workshops that students and academics had attended; rating of students' performance after attending the workshops; perceptions of the relevance of the services; and suggestions and recommendations for improvement.

Purposive sampling was employed to select the academics. The study targeted academics who were actively involved in encouraging students to attend library training workshops. These academics were identified via the Google Plus file. For this study, all the lecturers who had more than one workshop request in 2016 during the period of February to July were identified as active participants. At the time of the study, a total of fifty-one lecturers had made requests for training workshops in 2016, but only twenty-four were identified as 'active'. Copies of the questionnaire were either emailed or hand delivered to these lecturers. A total of twenty lecturers responded. The main challenge encountered in the study was eliciting responses from the academics.

The evaluation forms that were completed by the students at the end of each library workshop were reviewed. These evaluation forms were examined by information librarians after each training session to determine ways in which the workshops could be improved. It was noticed that the responses provided by students in the evaluation forms were quite similar, hence only thirty of the evaluation forms collected between February and July 2016 were randomly selected to support data for this study.

\section{Results and discussion}

In this study, the main objectives were:

- to establish the impact of the new library services on teaching, learning and research; and

- to establish the perceptions of users towards these services (based on the library's workshops).

\subsection{Academics' responses}

In order to address the first objective, a questionnaire was distributed to the academics that repeatedly made use of UNIZULU's library services.

Table 2 Demographic data of the academic staff $(\mathrm{N}=20)$

\begin{tabular}{lcc}
\hline Academic position & Value & Percentage \\
Junior Lecturer & 2 & $10 \%$ \\
Lecturer & 9 & $45 \%$ \\
Senior Lecturer & 2 & $10 \%$ \\
Associate Professor & 2 & $10 \%$ \\
Professor & 2 & $10 \%$ \\
Sen. Prof. & 2 & $10 \%$ \\
Other (Please specify) & 1 & $5 \%$ \\
Years of employment & Value & Percentage \\
Less than a year & 4 & $20 \%$ \\
$2-5$ years & 6 & $30 \%$ \\
$6-10$ years & 3 & $15 \%$ \\
$11-15$ years & 3 & $15 \%$ \\
$16-20$ years & 1 & $5 \%$ \\
$21+$ years & 3 & $15 \%$ \\
Faculty affiliation & Value & Percentage \\
Arts & 7 & $35 \%$ \\
Commerce, Admin and Law & 8 & $40 \%$ \\
Education & 3 & $15 \%$ \\
Science \& Agriculture & 2 & $10 \%$ \\
\hline
\end{tabular}

The demographic data in Table 2 shows that the majority of respondents were lecturers (45\%). Most of the respondents were employed at UNIZULU for over eleven years (35\%) and 30\% were employed for a period of between two to five years. Recently-recruited academics made up $20 \%$ of the sample. The majority $(40 \%)$ of the respondents were from the Faculty of Commerce, Administration and Law, followed by the Faculty of Arts (35\%), Faculty of Education (15\%), and Faculty of Science and Agriculture (10\%).

Figure 1 illustrates the purposes for which they used the library. The twenty academics used the library: to search for resources $(75 \%)$; for their own study $(75 \%)$; for library instruction $(70 \%)$; to attend library workshops $(70 \%)$; to consult with librarians $(60 \%)$; for inter-library loans $(30 \%)$; and other reasons $(5 \%)$. This finding shows that the academics were using 
the library for various purposes, including consultations with librarians, library workshops and library instruction, which could not be achieved without collaboration between librarians and academics. Kleinveldt, Schutte and Stilwell (2016: 65) emphasise the importance of such collaboration and knowledge sharing to support teaching, learning and research.

Figure 1 Purpose for using the library $(\mathrm{N}=20)$

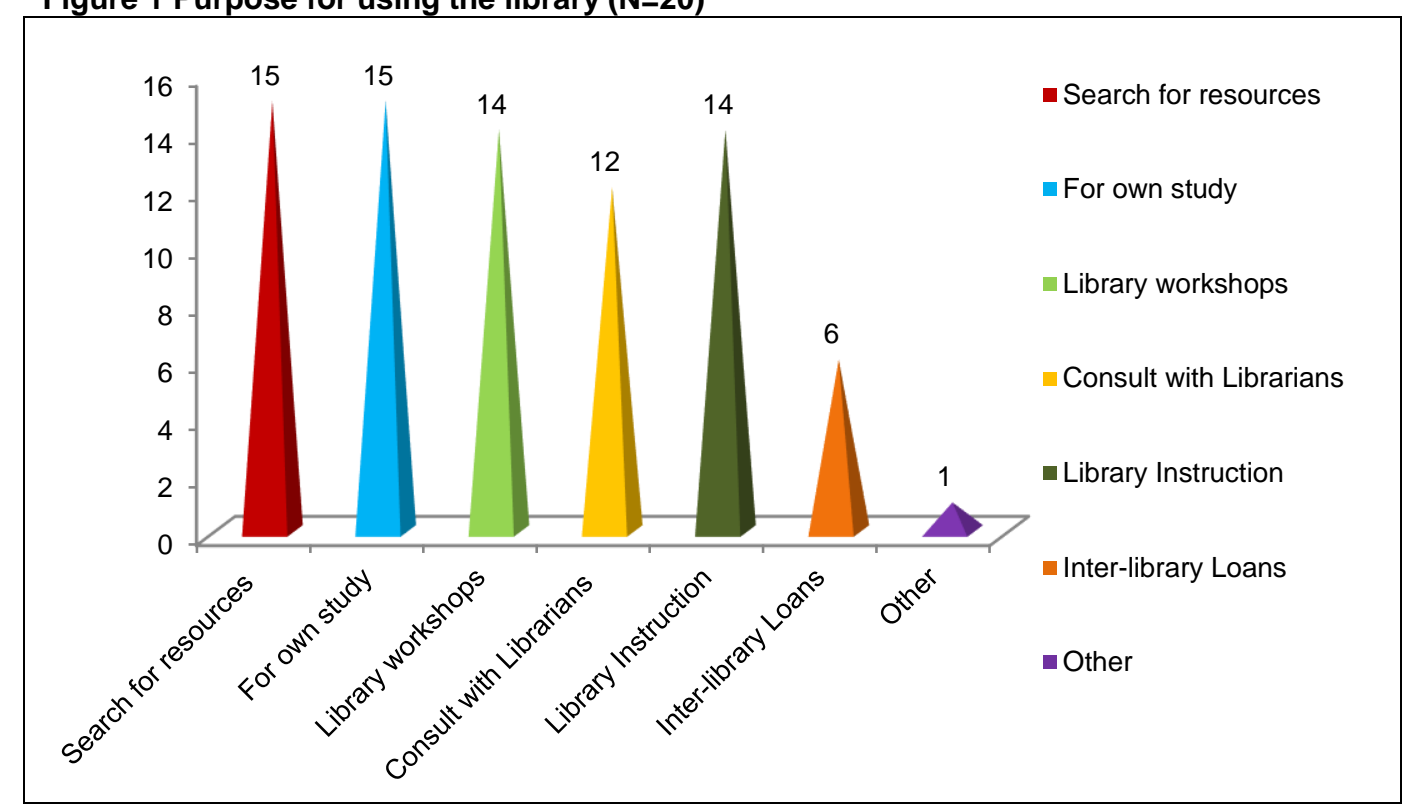

When asked which workshops they had booked for their students, the one on plagiarism proved to be the most popular, followed by e-resources, 'Know your library', and referencing as illustrated in Figure 2. A recent study by Ocholla and Ocholla (2016) noted that plagiarism continues to be a problem in higher education, which is why academics tend to prioritise it as a preventive measure, largely through education and training. E-resources, 'Know your library' and referencing workshops were at the top of the list because of their relevance.

Figure 2 Workshops attended $(\mathrm{N}=20)$

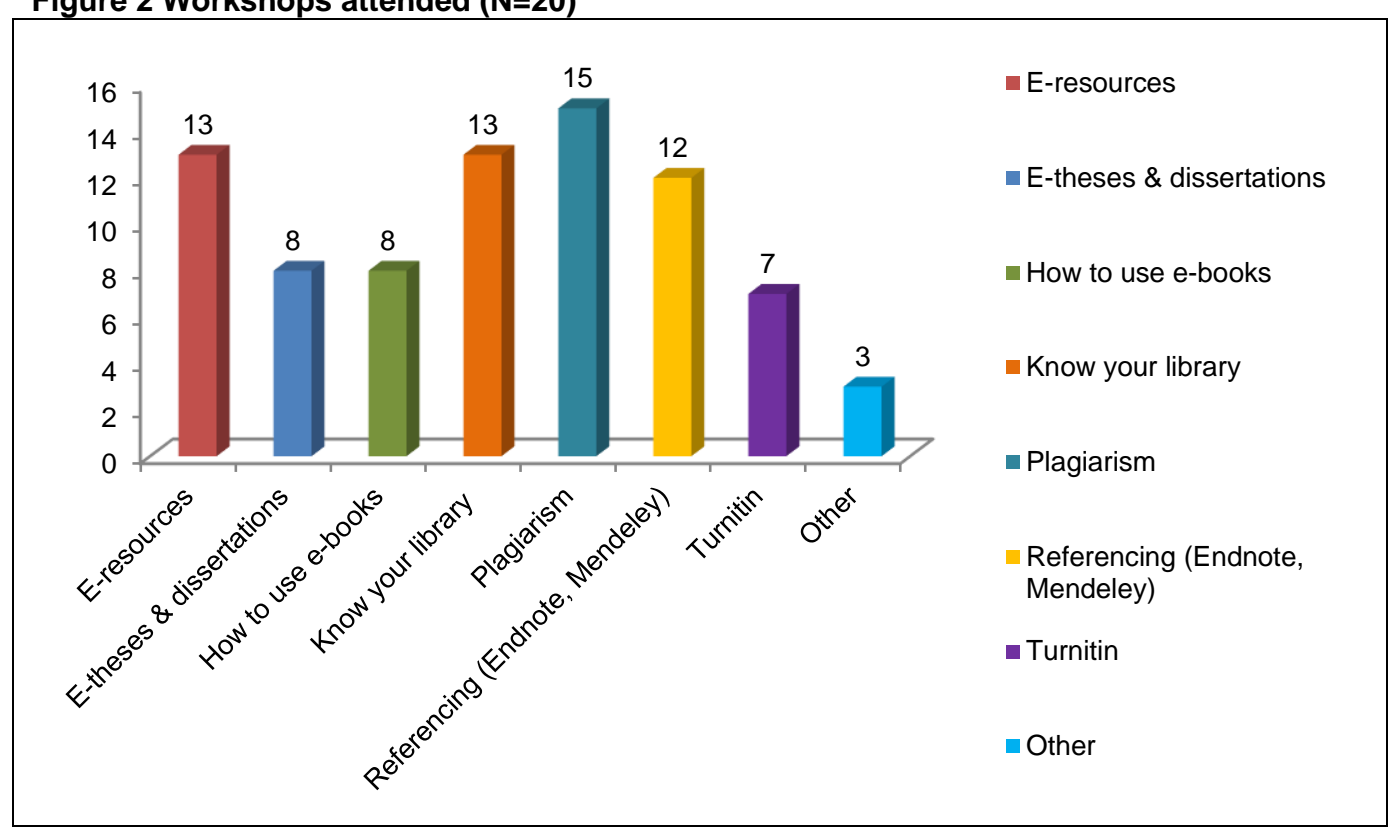

Table 3 shows that the impact of the workshops on students' performance was generally viewed to be positive. 'Know your library' was rated as very helpful, followed by e-resources, referencing, Turnitin, e-Theses and Dissertations (ETDs), and e-books. This corroborates Shao and Purpur's (2016) study on the effects of information literacy skills on student writing and course performance. The workshop on funding opportunities (based on Research Africa) was the least popular, perhaps because the impact could not be visible within a short period of time.

Respondents were asked about their students' performance after attending the workshops. Nineteen (95\%) respondents noticed a marked improvement in students' performance while one indicated that improvement was average. When asked about the perception regarding the library's workshops, the majority (95\%) of respondents rated the workshops as informative, "helpful with visible and invisible benefits", and some noted that the workshops were "essential for research". 
Under suggestions and recommendations, issues of time allocation, practical work, and the necessity of these training programmes to be included in the curriculum were highlighted. Librarians were praised for a job well done: one statement, for example, said that "the library is at the top of its game!"

Table 3 Relevance and impact of individual workshops $(\mathrm{N}=20)$

\begin{tabular}{|c|c|c|c|c|c|c|c|c|c|c|}
\hline Workshops & $\begin{array}{c}\text { Very } \\
\text { helpful }\end{array}$ & $\%$ & Helpful & $\%$ & $\begin{array}{c}\text { No } \\
\text { difference }\end{array}$ & $\%$ & $\begin{array}{c}\text { Not } \\
\text { helpful }\end{array}$ & $\%$ & $\begin{array}{l}\text { Waste } \\
\text { of time }\end{array}$ & $\%$ \\
\hline E-resources & 10 & $50 \%$ & 4 & $20 \%$ & 0 & $0 \%$ & 0 & $0 \%$ & 0 & $0 \%$ \\
\hline e-Theses and Dissertations & 4 & $20 \%$ & 4 & $20 \%$ & 1 & $5 \%$ & 0 & $0 \%$ & 0 & $0 \%$ \\
\hline Funding opportunities & 0 & $0 \%$ & 1 & $5 \%$ & 3 & $15 \%$ & 1 & $5 \%$ & 1 & $5 \%$ \\
\hline How to use e-books & 4 & $20 \%$ & 3 & $15 \%$ & 1 & $5 \%$ & 0 & $0 \%$ & 0 & $0 \%$ \\
\hline Know your library & 12 & $60 \%$ & 2 & $10 \%$ & 0 & $0 \%$ & 0 & $0 \%$ & 0 & $0 \%$ \\
\hline Plagiarism & 8 & $40 \%$ & 8 & $40 \%$ & 1 & $5 \%$ & 0 & $0 \%$ & 0 & $0 \%$ \\
\hline $\begin{array}{l}\text { Referencing (Endnote, } \\
\text { Mendeley) }\end{array}$ & 4 & $20 \%$ & 8 & $40 \%$ & 2 & $10 \%$ & 0 & $0 \%$ & 0 & $0 \%$ \\
\hline Turnitin & 4 & $20 \%$ & 4 & $20 \%$ & 0 & $0 \%$ & 0 & $0 \%$ & 0 & $0 \%$ \\
\hline $\begin{array}{l}\text { Other (please specify) Easy } \\
\text { data }\end{array}$ & 2 & $10 \%$ & 0 & $0 \%$ & 0 & $0 \%$ & 0 & $0 \%$ & 0 & $0 \%$ \\
\hline
\end{tabular}

\subsection{Students' responses}

In order to address the second research objective of this study on the perceptions of users towards the library workshops, thirty evaluation forms were randomly selected from the workshops that were attended by students in 2016 (February to July).

Figure 3 illustrates the students' responses, showing that the most-attended workshop was referencing with Endnote (77\%), followed by e-resources (67\%), 'Know your library' (57\%), plagiarism (57\%) and Turnitin (57\%).

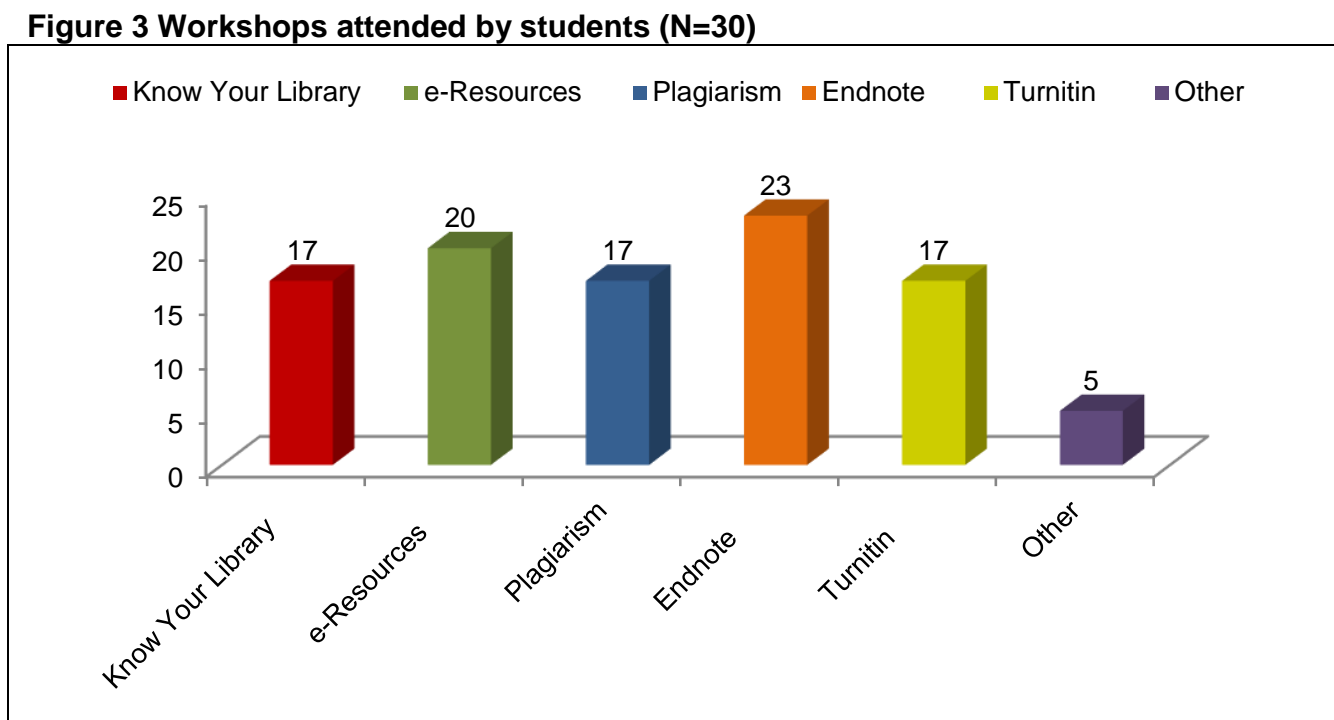

Regarding the question of whether the workshops were informative or not, the majority indicated that the workshops were "very informative" (53.5\%) and "informative" (46.5\%) as shown in Figure 4, which supports Liu, Lo and Itsumura (2016) findings on students' positive perception of library workshops. Students rated the quality of the presentations (Figure $5)$ as "very good" (83.3\%), "good" (13.3\%) and "average" (3.3\%).

Some of the respondents found everything to be interesting during the training sessions, while others pinpointed referencing, Turnitin, plagiarism, and e-resources to be the most useful. Most of the participants rated the training facilities as good and convenient, but some indicated that the computers were slow.

When asked what should be improved, the responses were very different: they ranged from "organising more and longer workshops", to "providing training packs", "provision of refreshments" and "more practical work with specific assignments". 
Students also suggested that "more people should attend to improve research output at the institution"; making use of videos; longer training sessions; making it compulsory for all students; more interactive and mentally engaging sessions; and improving the marketing of the workshops. Others were satisfied with the current information services, calling them "amazing" and "good work".

Figure 4 Perceptions of the workshops $(\mathrm{N}=30)$

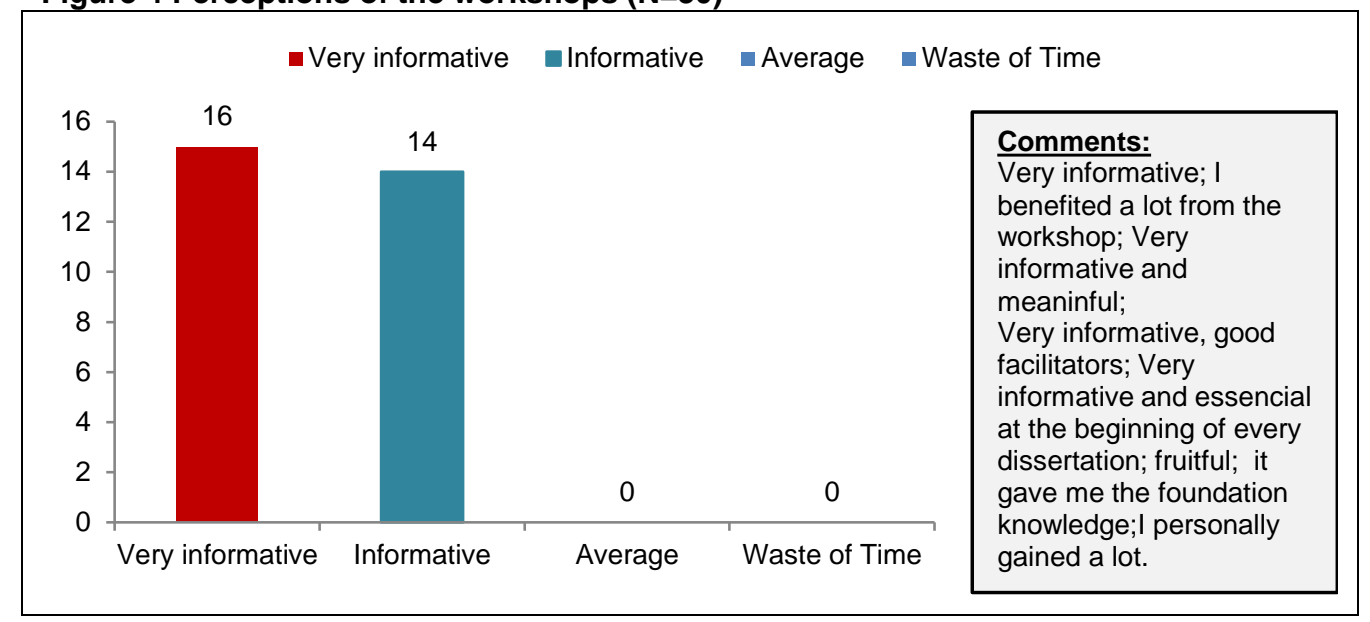

Figure 5 Quality of the presentations $(\mathrm{N}=30)$

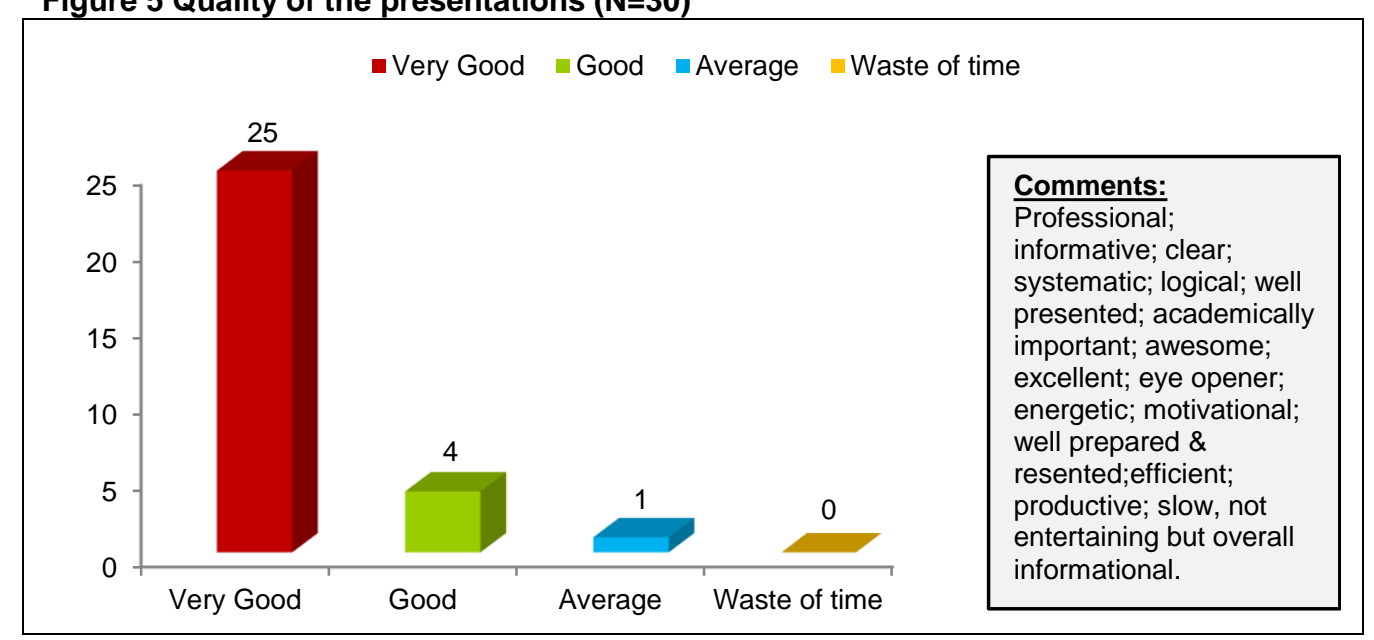

\section{Conclusion and recommendations}

The academics found the workshops to be useful for both themselves and their students. The workshops helped to improve their students' performance as well as their teaching experience. The students found the workshops useful, informative and relevant, and appreciated the initiative of the librarians. In similar studies (Julien et al. 2009, Appleton 2005, Shreeve \& Shelin 2014, Shao \& Purpur 2016), the overwhelming majority of students were in agreement that the instruction that they received in information literacy had a positive impact on their learning. Some of the benefits of the instruction cited by students were that it reduced the effort to find information, they had better grades following training, and that it enhanced their searching techniques (Julien et al. 2009:11).

Both the academics and students from the present study acknowledged the high level of presentation, skills, and knowledge of the librarians. The most useful topics in the presentations from the academics' perspective were: 'Know your library', e-resources, and plagiarism. Students found most of the presentations to be relevant, with referencing, Turnitin, plagiarism, and e-resources topping the list. Most of the participants found the facilities to be appropriate.

With the help of this study, it was possible to establish that the newly-introduced system of library workshops is not only appreciated by academics and students, but also positively impacts on students' performance. Information librarians have also benefited considerably from the whole process, echoing George Gurdjieff's ${ }^{6}$ famous assertion that, "By teaching others you will learn yourself."

Among the important lessons learnt, it was possible to: clearly identify and address user information needs for specific categories more effectively; improve information services to support research, teaching, and learning with a focused

6. See http://www.awaken.com/2013/06/quotes-by-george-gurdjieff 
approach on user needs; effectively reach more library users with only a few information librarians; develop new coverage of topics for library training; confirm the positive impact of a service on students' academic performance; obtain responses from the students about the new services; establish new and solid partnerships within the university structure (for example, with Research and Innovation and Teaching and Learning); improve library visibility and necessity; and enrich the information librarians' knowledge, skills, accountability, attitudes and confidence.

It was further observed that the library staff and their level of knowledge and skills required attention. Specifically, it was noted that the team of information librarians was understaffed: well-trained librarians are leaving for other institutions; new staff members require time to be trained; and the marketed services need to be sustained at a high level. It was also evident that information librarians' knowledge and skills need to be constantly developed and updated in order for them to be able to continue to provide a high quality of training.

Presently, the library's computer laboratory can only accommodate thirty people. This highlights the challenge of accommodating large classes of students. Academics and information librarians resort to identifying alternative venues such as lecture halls and computer laboratories to accommodate large groups. Alternatively, large classes have to be divided into groups, requiring more time and effort from all involved - the lecturers to allocate their lessons and arrange for the students to attend, and the librarians to book the library venue which is in high demand, especially when library orientation is taking place. The library's computer laboratory facilities therefore need significant improvement.

The information librarians noticed that computer literacy is still a problem for students and, in some cases, staff. Authors such as Adeleke and Emeahara (2016) and Robabi and Arbabisarjou (2015) have suggested that there is a causal relationship between computer literacy and the use of e-resources - that the more computer literate the students, the larger the increase in the use of e-resources. The problem of computer literacy at UNIZULU negatively affects the implementation and effective use of the E-learning Management System (ELMS), Moodle, which is used by the university. Only a small number of academics and students use this system, which makes it difficult for librarians to provide online teaching and learning support through Moodle.

It is recommended that:

- $\quad$ an information literacy course that is taught by librarians be implemented in the curriculum for all first-year students to improve their performance;

- $\quad$ the compulsory induction of postgraduate students includes all library workshops that support research;

- library staffing be addressed to enable the provision of quality information services on different levels to support teaching, learning, and research;

- librarians' training needs become a priority, especially in new areas such as research data management, open access, library as publisher, and digital wellness, to name a few;

- $\quad$ training facilities be uplifted, and new facilities with greater capacity be designed in the library;

- $\quad$ online and print training packs be prepared and provided;

- librarians and academics work together to speed up the implementation and use of the ELMS to support online teaching and learning; and

- $\quad$ existing library collaborations/co-operations be maintained, and new ones developed.

\section{References}

ACRL. 2011. Standards for Libraries in Higher Education, Association of College and Research Libraries. [Online]. http://www.ala.org/acrl/standards/standardslibraries (29 April 2016).

ACRL. 2015. Framework for Information Literacy for Higher Education. [Online]. http://www.ala.org/acrl/standards/ilframework (9 January 2017).

Adeleke, D.S. and Emeahara, E.N. 2016. Relationship between information literacy and use of electronic information resources by postgraduate students of the University of Ibadan. Library philosophy and practice. [Online]. http://digitalcommons.unl.edu/libphilprac/1381 (12 January 2017).

Appleton, L. 2005. Examination of the impact of information-skills training on the academic work of health-studies students: a single case study. Health Information and Libraries Journal, 22(3): 164-172.

Auckland, M. 2012. Reskilling for research: an investigation into the role and skills of subject and liaison librarians required to effectively support the evolving information needs of researchers. Research libraries UK. [Online]. http://www.rluk.ac.uk/wp- content/uploads/2014/02/RLUK-Re-skilling.pdf (10 January 2017).

Bowles-Terry, M. 2012. Library instruction and academic success: a mixed-methods assessment of a library instruction program. Evidence Based Library Information Practice, 7(1): 82-95.

Bryan, J.E. 2016. The preparation of academic librarians who provide instruction: a comparison of first and second career librarians. The Journal of Academic Librarianship, 42: 340-354.

Han, S. Wong, R. and Webb, T. 2011. Uncovering meaningful correlation between student academic performance and library material usage. College and Research Libraries, 72(4): 361-370.

Julien, H., Detlor, B., Serenko, A. Willson, R. and Lavallee, M. 2009. Outcomes of information literacy instruction for undergraduate business students: Proceedings of the Association for Information Science and Technology, 46(2): 1 18.

Kleinveldt, L.T, Schutte, M. and Stilwell, C. 2016. Embedded librarianship and Blackboard usage to manage knowledge and support blended learning at a South African university of technology. South African Journal of Libraries and Information Science, 82 (1): 27-38. DOI:10.7553/82-1-1592 (9 January 2017). 
Kot, F.C. and Jones, J.L. 2014. The impact of library resource utilization on undergraduate students' academic performance: a propensity score matching design. College and Research Libraries, 76(5): 566-586.

Liu, Q., Lo, P. and Itsumura, H. 2016. Measuring the importance of library user education: a comparative study between Fudan University and the National Taiwan Normal University. The Journal of Academic Librarianship, 42(6): 644-654. DOI:10.1016/j.acalib.2016.08.009.

Madukoma, E., Onuoha, U.D., Omeluzor, S.U. and Ogbuiyi, S. 2013. Library instruction and academic performance of undergraduates at Babcock University, Nigeria. Contemporary Humanities, 6: 39-58.

Matthew, J.R. 2015. Library assessment in higher education. $2^{\text {nd }}$ ed. Santa Barbara, California: Libraries Unlimited.

Ocholla, D.N. and Ocholla L. 2016. Does open access prevent plagiarism in Higher Education? African Journal of Library, Archives and Information Science, 26(2): 189-202.

Ocholla, L. 2016. The new roles of university libraries in supporting scholarly communication and research: a South African university library perspective. [Online]. http://www.gpntb.ru/win/inter-events/crimea2016/disk/003.pdf (25 July 2016).

Pasipamire, N. 2015. Research support by subject librarians in selected state university libraries in Zimbabwe: accommodating new trends. In The quest for deeper meaning of research support. R. Raju, A. Adam, G. Johnson, C. Miller and J. Pietersen, eds. Cape Town: University of Cape Town Libraries. 61-79. DOI:10.15641/0-7992- 2522-8 (17 August 2016).

Pham, H.T. and Tanner, K. 2014. Collaboration between academics and librarians: a literature review and framework for analysis. Library Review, 63(1/2): 15-45.

Raju, R. and Schoombee, L. 2013. Research support through the lens of transformation in academic libraries with reference to the case of Stellenbosch University Libraries. South African Journal of Libraries and Information Science, 79(2): 27-38. [Online]. http://sajlis.journals.ac.za/pub/article/view/155 (24 July 2016).

Robabi, H. and Arbabisarjou, A. 2015. Computer literacy among students of Zahedan University of Medical Sciences. Global Journal of Health Science, 7(4): 1-16. [Online]. http://www.ccsenet.org/journal/index.php/gjhs/article/view/40274/23987 (12 January 2017).

Schoombee, L. 2013. Research support services at an academic library. Presented at the University of the Free State 27 November. [Online]. http://www.slideshare.net/luciaschoombee/research-support-services-at-an-academic-librarypresented-at-ufs-27112013 (24 May 2016).

Schwartz, M. 2016. Top skills for tomorrow's librarians: careers 2016. Library Journal. [Online]. http://lj.libraryjournal.com/2016/03/careers/top-skills-for-tomorrows-librarians-careers-2016 (3 September 2016).

Shao, X. and Purpur, G. 2016. Effects of information literacy skills on student writing and course performance. The Journal of Academic Librarianship, 42(6): 670-678.

Shreeve, S. and Chelin, J. 2014. Value and impact of librarians' interventions on student skills. New Review of Academic Librarianship, 20 (2): 204-232. DOI:10.1080/13614533.2014.906351 (10 January 2017).

Tise, E., Raju, R. and Adam, A. 2015. From research support to research partners. In The quest for deeper meaning of research support. R. Raju, A. Adam, G. Johnson, C. Miller and J. Pietersen, eds. Cape Town: University of Cape Town Libraries. 1-12. DOI:10.15641/0-7992- 2522-8 (5 August 2016).

University of Zululand. 2016. Strategic Plan 2016-2021. [Online]. http://www.unizulu.ac.za/wpcontent/uploads/2016/09/UniZulu-Strat-Plan- 2016-2021.pdf (7 January 2017).

Vance, J. M., Kirk, R. and Gardner, J. G. 2012. Measuring the impact of library instruction on freshman success and persistence. Communications in Information Literacy, 6(1), 49-58.

Westbrock, T. and Fabian, S. 2010. Proficiencies for instruction librarians: is there still a disconnect between professional education and professional responsibilities? College \& Research Libraries, 71: 569-590. [Online]. http://crl.acrl.org/content/71/6/569.full.pdf (25 July 2016).

Wong, S. H.R. and Cmor, D. 2011. Measuring association between library instruction and graduation GPA. College \& Research Libraries, 72(5), 464-473. 